\title{
Trout Steroidogenic Testicular Cells in Primary Culture
}

\section{Steroidogenic Activity of Interstitial Cells, Sertoli Cells, and Spermatozoa}

\author{
Maurice Loir \\ Physiologie des Poissons, INRA, Campus de Beaulieu, 35042 Rennes Cedex, France
}

Accepted July 19, 1989

\begin{abstract}
Somatic cells (interstitial cells and Sertoli cells) were prepared either as single cells or in clusters, from spermatogenic and mature trout testes, according to Loir (1988), and cultured

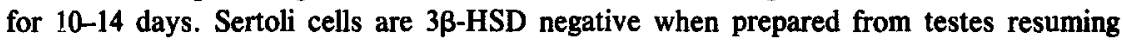
spermatogenesis and from mature testes, but they are $3 \beta$-HSD positive in spermatogenic testes. Progesterone, $17 \alpha$-hydroxyprogesterone (17 $\alpha-\mathrm{OH}-\mathrm{P})$, and free androgens are secreted by interstitial cells, 11 -ketotestosterone (11KT) being the predominating steroid produced immediately after seeding. These cells also produce high levels of glucuronated androgens. At least in mature spermiating testes they do not secrete estradiol. After isolation,

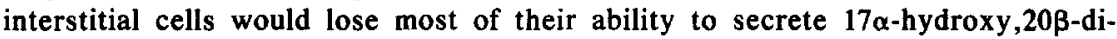
hydroprogesterone (17 $\alpha 20 \beta-\mathrm{OH}-\mathrm{P})$ but they would recover it later. Testicular spermatozoa, which convert $17 \alpha-\mathrm{OH}-\mathrm{P}$ independently of s-GtH, constitute a second source of this progestagen. In addition, our results suggest that Sertoli cells could be able to secrete $17 \alpha-\mathrm{OH}-\mathrm{P}$ and also progesterone. A possible participation of the intralobular production of the former progestagen to the local regulation of germ cell maturation is evoked. 1990 Academic Press, Ine.
\end{abstract}

Although extragonadal steroid sources participate in the steroid balance in trout (Schulz and Blüm, 1987), the testes produce the bulk of sex steroids and their precursors. Until recently, the cellular origin of the different steroids synthesized in the testis of teleosts has been a topic of controversy. There is now more evidence that Leydig cells are the main source of gonadal steroids in fish as in mammals: they possess enzymes involved in steroid hormone synthesis and ultrastructural features commonly found in steroid-producing cells.

While in mammals various data support the view that Sertoli cells are steroidogenic (Wiebe et al., 1987; for review, see Nagahama, 1986), in teleosts the steroidogenic capacities of these cells are still uncertain. Depending on the species, ultrastructural and histochemical data suggest the presence or absence of such a capacity. In trout, while juvenile Sertoli cells possess the basic ultrastructural features of ste- roidogenic cells (Upadhyay, 1977), this is less conclusive in adult Sertoli cells (Billard et al., 1972). On the other hand, the presence of $3 \beta$-HSD activity has been observed in trout Sertoli cells during a limited period (spermatogenesis; Van den Hurk et al., 1978).

In 1984, Ueda et al. showed that ejaculated sperm can convert 17 $\alpha$-hydroxyprogesterone $(17 \alpha-\mathrm{OH}-\mathrm{P})^{1}$ to $17 \alpha$-hydroxy,

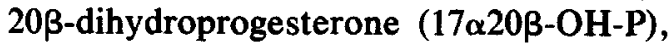
independently of $\mathrm{GtH}$. However, because GtH stimulated this progestagen production by testicular fragments, it still remains

\footnotetext{
${ }^{1}$ Steroid nomenclature: $17 \alpha-O H-P, 17 \alpha-$ hydroxyprogesterone, 17-hydroxy-4-pregnene3,20-dione; $17 \alpha 20 \beta-O H-P, 17 \alpha$-hydroxy, $20 \beta$-dihydroprogesterone, $17,20 \beta$-dihydroxy-4-pregnen-3-one; androstenedione, 4androstene-3,17-dione; $11 \mathrm{KT}, 11$-ketotestosterone, 17 $\beta$-hydroxy-4-androstene-3,11-dione; 4-ene pathway, $\Delta^{4}$ pathway.
} 
unresolved whether another cell type in the testis is a source of GtH-responsive $17 \alpha 20 \beta-O H-P$ production (Nagahama, 1987; Saad and Depéche, 1987).

Recently, we have put forward (Loir, 1988) a method to prepare cell populations enriched either in interstital cells or in Sertoli cells from trout testes at any maturation stage, and to culture them for 1-2 weeks. In this paper, we report data dealing with the steroidogenic activity of these cells.

\section{MATERIALS AND METHODS}

Animals. Males of autumn-spawning and springspawning strains of rainbow trout were kept in recycled freshwater at $12-15^{\circ}$ under natural photoperiod.

The maturation stage of the testes was determined according to Billard and Escaffre (1975). Stage III corresponds to the beginning of spermatogenesis, stages IV and V to spermatogenesis, and stages VII and VIIIa to mature spermiating testes.

Preparation of testis cell populations, cell separation, and culture. A total of 10 testicular cell separations were run, with two fishes at maturation stage III, one at stage V, one at stage VI, two at stages VIIVIIIa, and four at stage VIIIa.

The technique used to prepare testis cell populations and to culture them for 2 weeks has been described elsewhere (Loir, 1988, 1990). In brief, dissociation of a testis was achieved by perfusion with a collagenase plus pronase solution. Most of the spermatozoa were removed by the isodensity Percoll centrifugation method (reduction by about $\mathbf{5 0 0}$ times). Using flow sedimentation at unit gravity, the resulting cell suspension was fractionated into an "isolated cell" population and a "cell cluster" population. Each of these populations was fractionated into three cell populations by isopyknic centrifugation in Percoll gradients (isolated cell populations were numbered 1 to 3 ; cell cluster populations were numbered 4 to 6 ). In terms of somatic cell composition, populations 1 and 4 were enriched with interstitial cells (contamination of population 4 by Sertoli cells $\leqslant 4 \%$ of the somatic cells, except with stage III testes; Table 1), while populations 3 and 6 were enriched with Sertoli cells (contamination of population 6 by interstitial cells $\leqslant 4 \%$ of the somatic cells; Table 1). Contamination by other somatic cells was mainly due to macrophages in population 1. Round germ cells and spermatozoa were present, mainly in populations $1-3$, in variable numbers depending on the testes. These various populations were cultured in Leibovitz L15 medium, supplemented with $2 \%$ Ultroser (steroid-free serum substitute, IBF, France), in plastic multiwell plates coated with fibronectin. Every cell population was seeded in three wells. Around 2 to $5 \times 10^{6}$ cells $/ \mathrm{ml}$ were seeded in culture. Highly purified salmon gonadotropin (sGtH; Breton et al., 1978) was either added (usually 100 $\mathrm{ng} / \mathrm{ml}$ ) or omitted.

Cell identification, counting, and viability. Criteria for the identification of interstital cells, Sertoli cells,

TABLE 1

Distribution $(\times 10 \%$ ml) of Interstitial Cells (IC), Sertoli Cells (SC), and Spermatozoa (Sp) in Cell Populations Obtained after Density Gradient Centrifugation and Prepared from Testes at Maturation Stages III and VIIIa

\begin{tabular}{|c|c|c|c|c|c|c|c|c|c|c|}
\hline \multirow[b]{3}{*}{ Stage } & \multirow[b]{3}{*}{ Cells } & \multicolumn{9}{|c|}{ Cell populations } \\
\hline & & \multicolumn{3}{|c|}{ Isolated cells } & \multicolumn{3}{|c|}{ Cell clusters } & \multicolumn{3}{|c|}{ Round test. cells } \\
\hline & & 1 & 2 & 3 & 4 & 5 & 6 & a & b & c \\
\hline \multirow{3}{*}{$\begin{array}{l}\text { III } \\
\text { (5) }\end{array}$} & IC & 0.12 & 0.75 & 0.56 & 0.02 & 0.73 & 0.02 & & & \\
\hline & SC & 0 & 0.05 & 0.14 & 0.20 & 0.73 & 2.23 & & & \\
\hline & $\mathbf{S p}$ & 15 & 14 & 9 & 0.45 & 2.9 & 3.9 & & & \\
\hline \multirow{3}{*}{$\begin{array}{l}\text { VIIIa } \\
\text { (2) }\end{array}$} & IC & 2.45 & 1.15 & 0.80 & 3.0 & 1.05 & 0.3 & 1.3 & 0.55 & 0.25 \\
\hline & SC & 0.15 & 0.70 & 5.85 & 0.1 & 1.05 & 7.8 & 0.15 & 1.65 & 4.95 \\
\hline & Sp & 8.5 & 3.5 & 2.4 & 2.3 & 1.3 & 1.7 & 16.5 & 4.4 & 2.3 \\
\hline \multirow{3}{*}{$\begin{array}{c}\text { VIIIa } \\
\text { (3) }\end{array}$} & IC & & & & 1.2 & 0.42 & 0.06 & & & \\
\hline & SC & & & & 0.04 & 0.44 & 4.60 & & & \\
\hline & $\mathrm{Sp}$ & & & & 12.7 & 4.1 & 6.5 & & & \\
\hline \multirow{3}{*}{$\begin{array}{l}\text { VIIIa } \\
\text { (4) }\end{array}$} & IC & & & & 0.70 & 0.58 & 0.08 & & & \\
\hline & SC & & & & 0.02 & 0.58 & 2.17 & & & \\
\hline & Sp & & & & 10.8 & 11.6 & 13.0 & & & \\
\hline
\end{tabular}

Note. Numbers in parentheses, corresponding figure. 
and germ cells, and of the nuclei of these cells, have been given elsewhere (Loir, 1988, 1990). Nuclei of cells, either in suspension or spread onto plastic, were prepared with $0.4 \%$ hexadecyltrimethylammonium bromide. Cells in suspension and nuclei were counted using a hemocytometer on a phase contrast microscope. Cell viability was determined by the $0.2 \%$ erythrosine B dye exclusion test (Philips, 1973).

Identification of the steroidogenic cells. Histochemical staining for $3 \beta$-HSD was performed by modifying the method of Levy et al. (1959) as described by Loir (1988). Briefly, after washing, the cells were frozen at $-70^{\circ}$ either in $6 \%$ dextran $(\mathrm{W} / \mathrm{V})$ in phosphatebuffered saline (cells in suspension) or in the reaction mixture without the steroid (cells onto plastic). After thawing, the reaction mixture was added and this was then incubated at $37^{\circ}$ for $45 \mathrm{~min}$. The percentage of violet-stained cells was estimated and used to determine, after the total cell counts, the number of Leydig cells per milliliter. The reaction mixture consisted of 1 vol $1 \mathrm{mg} 5 \beta$-androstan-3 $\beta$-ol-17-one/ml DMSO, 1 vol 2 mg tetranitro blue tetrazolium $/ \mathrm{ml} \mathrm{H}_{2} \mathrm{O}, 4$ vol $0.1 M$, $\mathrm{pH} 7.2$, phosphate buffer, and 4 vol $6 \mathrm{mg} \mathrm{NAD} / \mathrm{ml}$ phosphate buffer. The steroid was omitted from the control samples.

Steroid radioimmunoassays (RIA). Steroids were assayed in the culture medium after extraction with ethylacetate:cyclohexane (50:50), except progesterone which was extracted with hexane. No chromatography was carried out.

Progesterone was assayed according to Lecouteux et al., (1985). The RIA for 17- $\alpha$-hydroxyprogesterone (17 $\alpha-\mathrm{OH}-\mathrm{P})$ was performed as for 11-ketotestosterone (11KT) (Fostier et al., 1982). 17 $\alpha$-Hydroxy, 20 $\beta$-dihydroprogesterone $(17 \alpha, 20 \beta-O H-P)$ RIA was performed according to Fostier and Jalabert (1986). Androstenedione and 11KT RIAs were performed as described by Fostier et al. (1982). Estradiol-17及 $\left(\mathrm{E}_{2}\right)$ was assayed as described by Terqui et al. (1973). For all these RIAs, the main cross-reactivities were usually under $5 \%$ with the other progestagens and androgens (Loir, 1990).

The "total androgens" RIA was performed as for 11KT using an antibody against testosterone-3-CMO BSA. The main cross-reactivities were with $5 \alpha$-dihydrotestosterone $(84 \%), 11 \mathrm{KT}(61 \%)$, 5 $\alpha$-androstane-3 $\alpha, 17 \beta$-diol $(89 \%), 5 \alpha$-androstane$3 \beta, 17 \beta$-diol $(26 \%)$, and androsterone $(18 \%)$. Conjugated androgens were assayed after treatment with Helix pomatia enzyme solution (IBF, France; 1700 Fishman units of $\beta$-glucuronidase and 17,000 Roy units of sulfatase) of the aqueous residues remaining after assay of the free androgens.

The sensitivity was $5 \mathrm{pg} / \mathrm{ml}$ for the androgens, $17 \alpha-O H-P$ and $17 \alpha, 20 \beta-O H-P, 2 \mathrm{pg} / \mathrm{ml}$ for $E_{2}$, and 10 $\mathrm{pg} / \mathrm{ml}$ for progesterone. Intraassay coefficients of variation were under $10 \%$ for all steroids. Usually, steroids were assayed in triplicate. However, because the volume of medium per well was small ( 400 or $1800 \mu \mathrm{l})$ and the concentration of some steroids was low when more than two or three steroids were assayed, one or two steroids were assayed in triplicate while the others were assayed in the pool of the three remaining culture media. In this case, no standard error (SE) could be calculated. When SE was calculated, the coefficient of variation was usually lower than $12 \%$.

\section{RESULTS}

\section{3ß-Hydroxysteroid Deshydrogenase Activity. (Fig. 1)}

After histochemical staining, the Leydig cells present in both interstitial cell populations (isolated cells and cell clusters) prepared from stage III, V, and VII-VIIIa testes displayed a similar mean individual $3 \beta$-HSD activity at the time of seeding. In addition, they had the same morphological appearance. As early as 2.5 days in culture, and later, the mean individual 3 $\beta$-HSD activity was somewhat higher for the Leydig cells in clusters than for the isolated ones. Mean individual activity was often maximal after 5 days in culture decreasing slowly thereafter. After 7-15 days, the morphology of the two types of Leydig cells was different: usually, the isolated ones were rather thin and elongated while in the cell cluster populations, such cells were mixed with numerous interstitial cells that had a better appearance and were rather broad and slightly larger.

Sertoli cells prepared from a stage III testis were $3 \beta$-HSD negative at the time of seeding and throughout culture duration. For the most part, this was also true when the cells were prepared from stage VIIVIIIa testes (five fishes, $3 \beta-H S D$ negative; one fish, slightly $3 \beta-H S D$ positive). Sertoli cells prepared from stage $V$ testes (three fishes) were constantly moderately $3 \beta$ HSD positive.

\section{Steroids Secreted during the First I to 2.5 Days after Seeding. (Figs. 2-6)}

The amounts of $11 \mathrm{KT}$ secreted in the presence of s-GtH in the medium, by each 

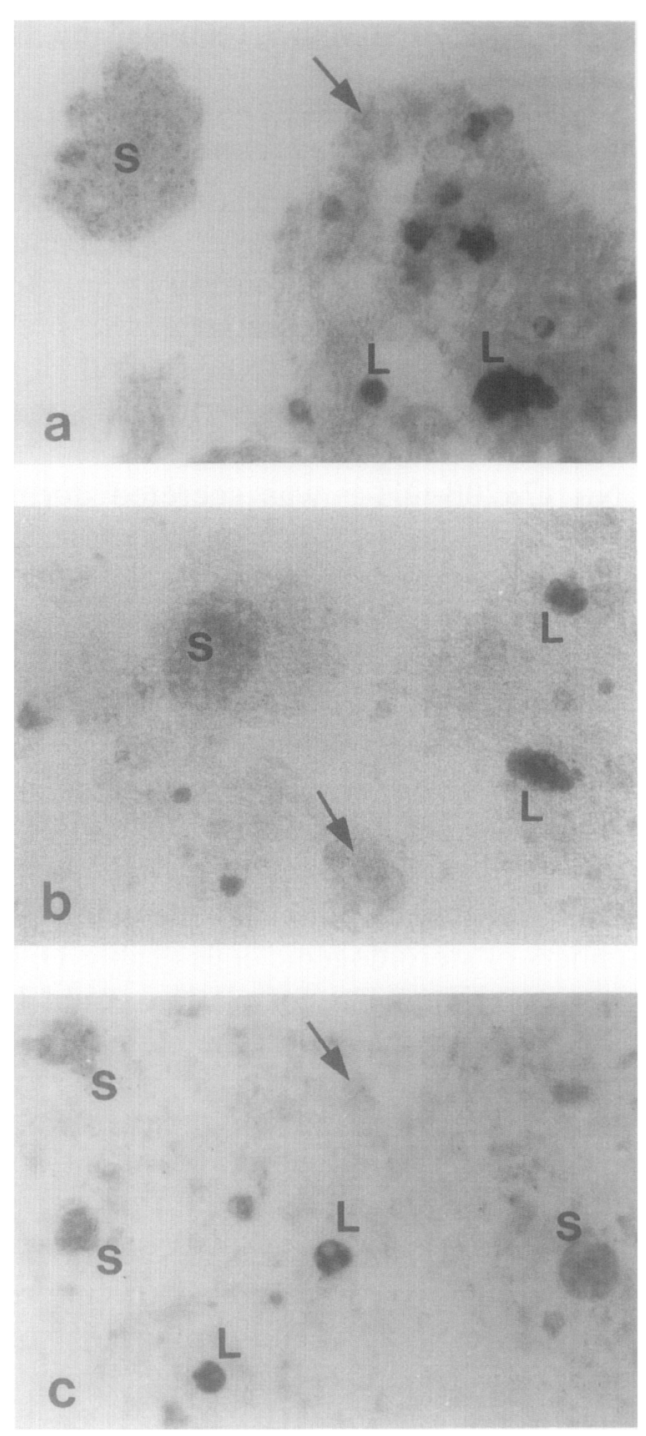

FIG. 1. Light micrographs of $3 \beta$-hydroxysteroid deshydrogenase staining of round testicular cells prepared from testes at stages VIIIa (a and b) and V (c). Leydig cells $(\mathrm{L})$ were constantly highly stained. Sertoli cells (S) were usually unstained (staining identical to that of nonsteroidogenic cells; arrows) at stage VIIIa, except for one male (b). They were moderately stained at stage $\mathrm{V}$.

of the three isolated cell populations (populations 1 to 3) and by each of the three cell cluster populations (populations 4 to 6 ), prepared from testes at the maturation stages III and V to VIIIa (10 fishes), were roughly proportional to the number of

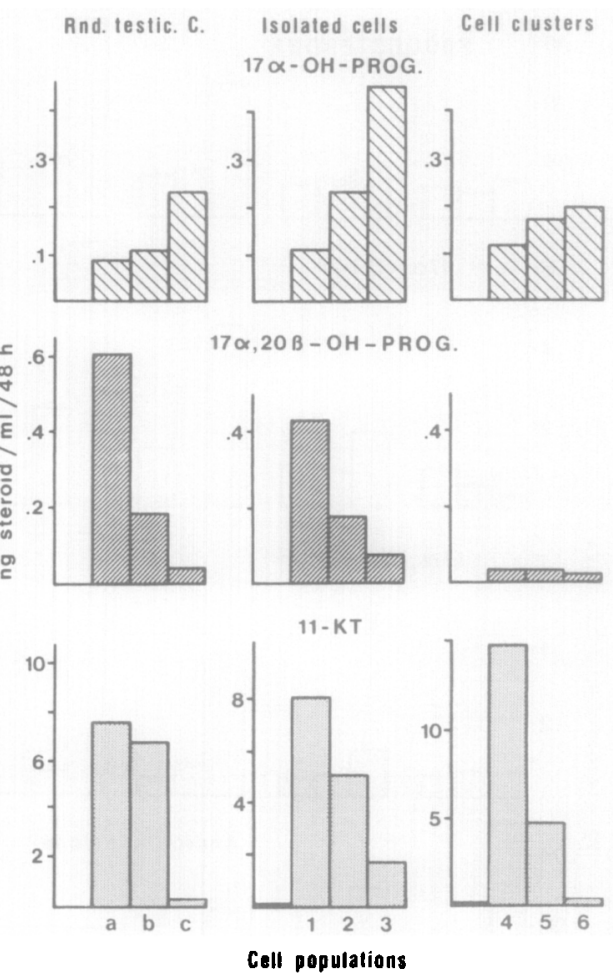

FIG. 2. GtH-stimulated $(120 \mathrm{ng} / \mathrm{ml})$ secretions by cell populations obtained after density gradient centrifugation of "isolated cells," "cell clusters," and unfractionated round testicular cells prepared from one stage VIIIa testis and cultured for $\mathbf{2 . 5}$ days. For cell numbers per milliliter in the various populations, see Table 1.

3 $\beta$-HSD positive interstitial cells present in these populations (Table 1). This was also true when total round testicular cells were separated onto Percoll gradients. In two experiments, the amounts of $11 \mathrm{KT}$ produced by the two "Sertoli cell" populations (populations 3 and 6) were much lower than that expected, taking into consideration the estimated number of steroidogenic cells. The same relationship between the amount of steroid secreted and the number of steroidogenic cells was also observed at the maturation stage VIIIa for androstenedione.

It was worth noting that s-GtH stimulated the $11 \mathrm{KT}$ secretion by the interstitial cells more efficiently when they were 


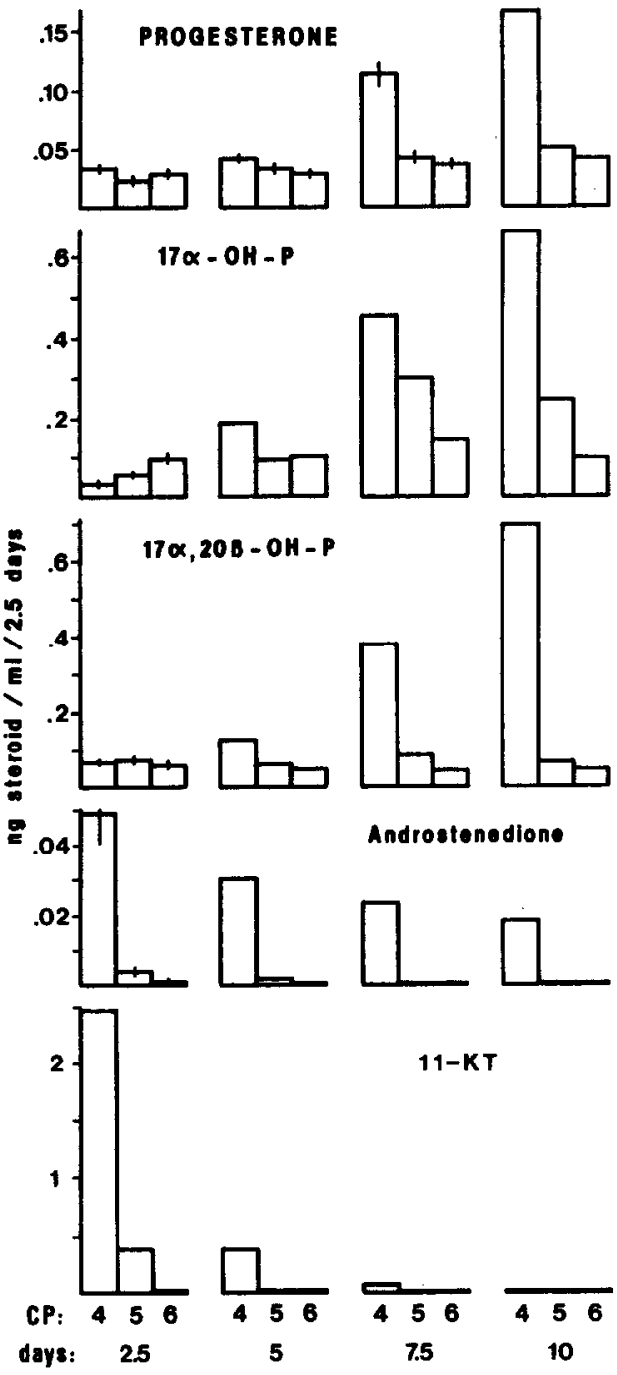

Fig. 3. Changes in the GtH-stimulated $(100 \mathrm{ng} / \mathrm{ml})$ secretions of five steroids by the cell populations (CP 4 to 6) obtained after gradient centrifugation of the "cell clusters" prepared from one stage VIIIa testis and cultured for 10 days. For cell numbers per milliliter, see Table 1 . Means of three wells \pm SE or pools of three wells (no SE).

seeded in clusters (population 4) than when they were isolated (population 1). Stimulation was by 11.5 times vs 4.7 times with one stage $V$ testis; by 7.9 times vs 1.5 times with one stage VI testis; and by 16 times vs 3.3 times with one stage VIIIa testis. Furthermore, the basal secretion by $10^{6}$ cells in clusters was often higher than that by $10^{6}$ isolated cells.

Progesterone and $17 \alpha-\mathrm{OH}-\mathrm{P}$ were secreted in low amounts by all six cell populations at all investigated maturation stages. These secretions were never significantly affected by s-GtH. Especially for $17 \alpha-$ $\mathrm{OH}-\mathrm{P}$, the amounts secreted in the presence of s-GtH appeared to be related more closely to the numbers of Sertoli cells than to those of steroidogenic cells.

No $17 \alpha 20 \beta-O H-P$ was secreted during the first 2.5 days in culture by any of the six cell populations prepared from stage III testes. With more mature testes (stages $\mathrm{V}$ to VIIla), this progestagen was secreted in low amounts by all cell populations. This secretion was not significantly influenced by s-GtH. There was no obvious correlation between the amounts of $17 \alpha 20 \beta-O H-P$ secreted in the presence of s-GtH by the various cell populations and the estimated numbers of steroidogenic cells (Table 1). In some experiments a correlation could be suspected to exist with the numbers of spermatozoa.

Spermatozoa mechanically prepared from stage VI testes (six testes) and cultured alone did not secrete $17 \alpha-\mathrm{OH}-\mathrm{P}$, whether s-GtH was present or not. When such spermatozoa were added to cultures of round testicular cells (prepared from stage VII-VIIIa testes; two experiments) which secreted $17 \alpha-\mathrm{OH}-\mathrm{P}$ for at least 7 days, higher amounts of $17 \alpha 20 \beta-\mathrm{OH}-\mathrm{P}$ were secreted than when the round cells were alone. This secretion was not stimulated by s-GtH. Simultaneously, the amounts of $17 \alpha-\mathrm{OH}-\mathrm{P}$ present in the medium were dramatically decreased.

\section{Changes in Steroid Secretions during Long-Term Cultures (Figs. 3-5)}

As already observed with cultures of round testicular cells (Loir, 1990), the secretions of androgens by the six cell populations, prepared from stages III and V to 


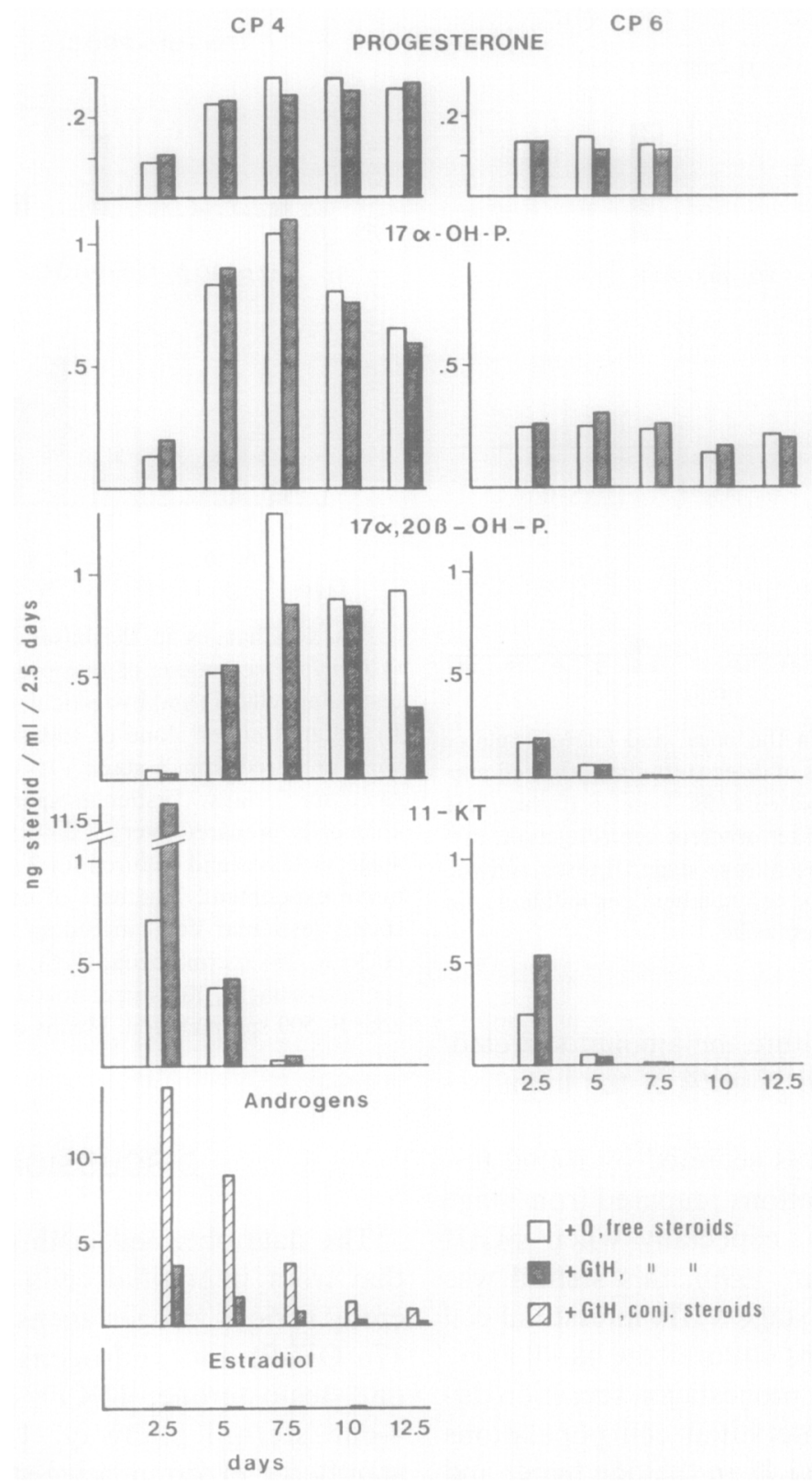

Fig. 4. Changes in the basal and GtH-stimulated $(100 \mathrm{ng} / \mathrm{ml})$ secretions of five steroids and of free and conjugated "total androgens" by the cell populations 4 (left) and 6 (right) obtained after gradient centrifugation of the "cell clusters" prepared from one stage VIIla testis and cultured for 12.5 days. For cell numbers per milliliter, see Table 1. Pools of three wells.

VIIIa, always decreased rapidly. After 10 days, $11 \mathrm{KT}$ was always undetectable in the culture medium (containing Ultroser) from interstitial cell populations while, at least at stages VII-VIIIa, androgens and T (essen- tially in the conjugated form) could be still detected, although in low amounts. At stage VIIIa, androstenedione secretion by the interstitial cells also decreased throughout culture but the decrease was slow. Af- 


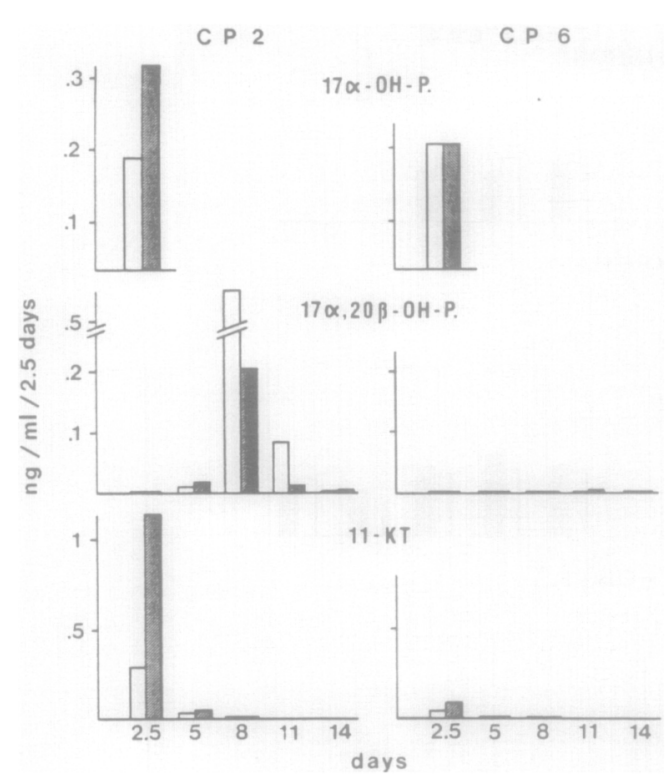

FIG. 5. Changes in the basal and GtH-stimulated $(180 \mathrm{ng} / \mathrm{ml})$ secretions of three steroids by the cell populations 2 (left; "isolated cells") and 6 (right; "cell clusters") obtained after gradient centrifugation, prepared from one representative stage III testis and cultured for 14 days. For cell numbers per milliliter, see Table 1. Pools of three wells.

ter 10 days in culture the amount secreted/ 2.5 days was still $37-42 \%$ of the initial secretion.

Although $E_{2}$ was secreted by round testicular cell populations prepared from stage VII-VIIIa testes, especially when s-GtH was present (Loir, 1990), this steroid was not produced by stage VIIIa interstitial cell cluster populations cultured during 10 days.

The changes in progestagen secretion differed between interstitial cell populations (populations 1 and 4) on the one hand, and Sertoli cell populations (populations 3 and 6 ) on the other. Indeed, progesterone, $17 \alpha-\mathrm{OH}-\mathrm{P}$, and $17 \alpha 20 \beta-\mathrm{OH}-\mathrm{P}$ secretions by interstitial cells increased conspicuously (14 to 75 times more after 10 days than after 2.5 days) at least up until 7.5 days or more. On the contrary, these secretions by the Sertoli cell populations either increased slightly or did not vary significantly or decreased.

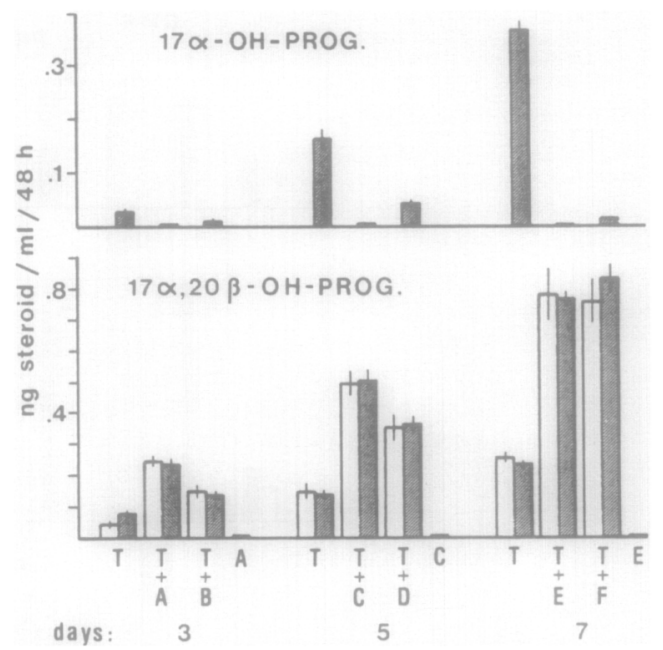

Fig. 6. Changes in the basal and GtH-stimulated $(120 \mathrm{ng} / \mathrm{ml})$ secretions of two progestagens by round testicular cells ( $T$ ) and by testicular spermatozoa (A to F) cultured either alone or together. Testicular cells were prepared from a stage VII-VIIIa testis and cultured for 7 days. Testicular spermatozoa were mechanically prepared every 2 days from three different stage VI testes and cultured for 2 days. One representative experiment. Numbers of cells $\times 10^{6} / \mathrm{ml}$ : T, 5.4 round testicular cells including about 0.27 Leydig cells; A, 244 spermatozoa; B, 61 spermatozoa; C, 416 spermatozoa; D, 104 spermatozoa; E, 2000 spermatozoa; F, 500 spermatozoa. Means of three wells $\pm \mathrm{SE}$.

\section{DISCUSSION}

The data obtained in this study confirm that trout interstitial cells are able to secrete various progestagens (progesterone, $17 \alpha-\mathrm{OH}-\mathrm{P}$ ) and androgens (androstenedione, testosterone, 11KT), involved in the 4-ene steroid pathway. 11KT was constantly the predominating steroid produced immediately after seeding. $E_{2}$ was not secreted by interstitial cells, at least at stage VIIIa. Previously (Loir, 1990), we have shown that these cells are able to conjugate androgens.

Our results demonstrated that isolated interstitial cells and interstitial cells in clusters differed in androgen production and re-

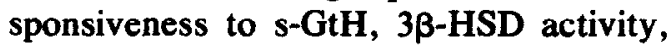
and morphology after several days in cul- 
ture. These differences could result from an enrichment of the two cell populations in Leydig cells with different metabolic characteristics. Indeed, in fish (Nicholls and Graham, 1972; Loir et al., 1988), as in mammals (Kerr et al., 1985), there exists in the testis, at least from an ultrastructural point of view, some heterogeneity of the Leydig cells. In mammals, this is reflected by different apparent buoyant densities in Percoll density gradients (Hedger and Eddy, 1987). In the present study, the Leydig cells present in the isolated interstitial cell and interstitial cell cluster populations have the same density $(1.048-1.062 \mathrm{~g} / \mathrm{ml}$; Loir, 1988). Moreover, at the time of seeding, Leydig cells of the two populations are

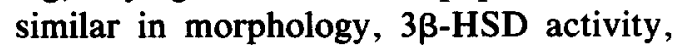
and ultrastructural features (unshown). So, we assume that after separation, the Leydig cells obtained in the two interstitial cell populations are identical. Their different steroidogenic activity and responsiveness to GtH throughout culture may be due either to other cell types present in the populations, for instance, macrophages which are abundant in population 1 and which could modulate Leydig cell activity (Verhoeven et al., 1988), or the disorganization and suppression of the intercellular contacts between interstitial cells. In the rat, Hedger and Eddy (1987) have proposed that there is cooperation among Leydig cells in vitro, possibly mediated by direct Leydig-Leydig cell contacts, and Verhoeven et al. (1986) have shown that steroid output and responsiveness to LH of reaggregated interstitial cells exceed those of cells maintained as monolayers.

In agreement with the data obtained by Ueda et al. (1984), we have pointed out that testicular (mature, nonspermiating testes) spermatozoa are able to convert $17 \alpha-\mathrm{OH}-\mathrm{P}$ (produced in this study by round testicular cells) to $17 \alpha 20 \beta-O H-P$ and that the $20 \beta$-oxydoreductase activity is insensitive to s-GtH. When testis fragments (either containing spermatozoa or not) were incu- bated for 20 or $24 \mathrm{hr}$ (Saad and Depéche, 1987; F. Le Gac, unpublished), the stimulation rate for $17 \alpha 20 \beta-O H-P$ was high (stimulation by 11 to 26 times) and higher than that observed for 11KT (stimulation by 4 to 11 times). This could suggest that in vivo, a testicular cell type possessing GtH receptors, likely to be Leydig cells, constitutes a second cellular source of $17 \alpha 20 \beta-O H-P$. However, as already observed with round testicular cells (Loir, 1990), the amounts of $17 \alpha 20 \beta-O H-P$ secreted by interstitial cell populations after 2.5 days in culture were low, as well as the stimulation rates by sGtH. Nevertheless, a shorter time after seeding (1 day; Loir, 1990), 17a20ß-OH-P production by round testicular cells appeared to be conspicuously stimulated by s-GtH. These data suggest that troutdissociated interstitial cells rapidly lose most of their ability to support GtHcontrolled 17 $20 \beta-\mathrm{OH}-\mathrm{P}$ production after dissociation and that the spermatozoa present at the beginning in the culture would be the main source of the low amounts of this progestagen secreted during the first 2-3 days after seeding. This situation could be induced by the dissociating treatment, as has been already proposed in Xenopus (Lecouteux, 1988) for androgen production. No data have clarified whether the ability to produce progesterone and $17 \alpha-\mathrm{OH}-\mathrm{P}$ is similarly affected. It is worth noting that trout testis dissociation would not affect the GtH-dependent 11KT production in the same time-related manner. Further investigations are needed to elucidate the possible role of disturbances induced by cell isolation and disorganization of testicular histology on the steroidogenic activity of trout Leydig cells.

In any case, whether trout interstitial cells produce low amounts of $17 \alpha 20 \beta-\mathrm{OH}-\mathrm{P}$ or not after testis dissociation, they become able to secrete increasing amounts of this progestagen after 2-3 days, although with a low sensitivity to $\mathrm{GtH}$. Indeed, because the contribution of gametes to $17 \alpha 20 \beta-O H-P$ 
production becomes rapidly negligible (progressive destruction of spermatozoa plus removal at every change of medium; Loir, 1988), the increasing amounts of $17 \alpha-$ 203-OH-P produced after 2.5 days are to be ascribed mainly, then exclusively, to interstitial cells. Simultaneously, these cells also secrete increasing amounts of progesterone and $17 \alpha-\mathrm{OH}-\mathrm{P}$.

After short culture durations, androgens secreted by Sertoli cell populations are likely due to contaminating interstitial cells. In the same way, contaminating interstitial cells and/or spermatozoa are the source of $17 \alpha 20 \beta-O H-P$. On the contrary, the amounts of progesterone and $17 \alpha-\mathrm{OH}-\mathrm{P}$ secreted by Sertoli cell populations are not correlated to the interstitial cell concentrations. In mammals, when Leydig cells were found with different buoyant densities, either they show similar biological activity (Aquilano and Dufau, 1984; Kerr et al., 1985; Hedger and Eddy, 1987) or the hCGstimulated testosterone production was lower in the light Leydig cells than in the heavy ones. In the trout, we have no data that shows that Leydig cells present in Sertoli cell populations represent a particular and scarce Leydig cell population which could secrete about as much androgens as the heavy Leydig cells but would secrete 10 to 24 times $(15.4 \pm 4.5, n=7)$ more $17 \alpha-\mathrm{OH}-\mathrm{P}$ than them. Or, light Leydig cells would be similar to the heavy ones but their ability to secrete $17 \alpha-\mathrm{OH}-\mathrm{P}$ and progesterone could be modified by the presence of Sertoli cells and/or by the low Leydig cell plating density.

Until now, it was uncertain whether trout Sertoli cells produce steroids. Histochemical and ultrastructural observations support, at least partly, our assumption that these cells-in addition to Leydig cellswould be able to secrete $17 \alpha-\mathrm{OH}-\mathrm{P}$ and progesterone in spermatogenic and mature testes. At stage $\mathrm{V}$, as already observed by Van den Hurk et al. (1978), Sertoli cells were slightly $3 \beta$-HSD positive. At more mature stages they appeared to be negative, but it cannot be excluded that some $3 \beta$-HSD activity was present but too low to be detected, more especially as, at these stages, the Sertoli cells contain smooth endoplasmic reticulum (Billard et al., 1972; Loir, 1988, 1989). Also, mitochondria with tubular cristae have been occasionally observed (Loir, 1988, 1989). Finally, in mammals, Sertoli cells, although unable to convert pregnenolone to progesterone, convert progesterone to a number of other steroids (Wiebe et al., 1987).

So, we propose, as a hypothesis to stimulate further study, that Sertoli cells could produce $17 \alpha-\mathrm{OH}-\mathrm{P}$ which would be converted to $17 \alpha 20 \beta-O H-P$ by spermatozoa. Because this latter progestagen is supposed to control spermiation (Nagahama, 1987) and is suspected to induce the concomitant decrease in androgen secretion (Le Gac and Loir, 1988), this mechanism could participate in the local regulation of spermatogenesis by coordinating the somatic cell activity implied in the spermiation process and the progressive maturation of the sperm cells. From this point of view, it should be mentioned that no correlation was observed between free $17 \alpha 20 \beta-O H-P$ plasmatic levels and free $17 \alpha 20 \beta-O H-P$ sperm (seminal plasma) levels (45 males rainbow trout; M. Loir, unpublished). This could suggest (1) that free $17 \alpha 20 \beta-O H-P$ present in each of both compartments originates mostly from this compartment (blood: Leydig cells; sperm: spermatozoa) and (2) a different function for this progestagen, depending on the considered compartment.

\section{ACKNOWLEDGMENTS}

This work was supported in part by a grant from the "Institut National de la Recherche Agronomique." We thank Dr. B. Breton for the kind gift of s-GtH and Dr. A. Fostier for helpful discussions. We are grateful to Mrs. Bougoussa and B. Mourot for technical assistance and to J. Hall for help with the English.

\section{REFERENCES}

Aquilano, D. R., and Dufau, M. L. (1984). Functional 
and morphological studies on isolated Leydig cells: Purification by centrifugal elutriation and metrizamide fractionation. Endocrinology 114, 499-510.

Billard, R., and Escaffre, A. M. (1975). Identification des stades de la spermatogenese de la truite fario d'aprés la morphologie des gonades et la spermiation. Bull. Fr. Piscic. 256, 111-118.

Billard, R., Jalabert, B., and Breton, B. (1972). I.es cellules de Sertoli des poissons teleosteens. I. Etude ultrastructurale. Ann. Biol. Anim. Biochim. Biophys. 12, 19-32.

Breton, B., Prunet, P., and Reinaud, P. (1978). Sexual differences in salmon gonadotropin. Ann. Biol. Anim. Biochim. Biophys. 18, 759-765.

Fostier, A., Billard, R., Legendre, M., and Marlot, S. (1982). Plasma 11-oxotestosterone and gonadotropin during the beginning of spermiation in rainbow trout (Salmo gairdneri). Gen. Comp. Endocrinol. 46, 428-434.

Fostier, A., and Jalabert, B. (1986). Steroidogenesis in rainbow trout (Salmo gairdneri) at various preovulatory stages: Changes in plasma hormone levels and in vivo and in vitro responses of the ovary to salmon gonadotropin. Fish Physiol. Biochem. 2, 87-99.

Hedger, M. P., and Eddy, E. M. (1987). The heterogeneity of isolated adult rat Leydig cells separated on Percoll density.gradients: An immunological, cytochemical, and functional analysis. Endocrinology 121, 1824-1838.

Kerr, J. B., Robertson, D. M., and de Kretser, D. M. (1985). Morphological and functional characterization of interstitial cells from mouse testes fractionated on Percoll density gradients. Endocrinology 116, 1030-1043.

Lecouteux, A. (1988). Gonadotropin action on androgen synthesis in short-term incubation of explants and dispersed cells of the testis of Xenopus laevis. J. Exp. Zool. 245, 187-193.

Lecouteux, A., Garnier, D. H., Bassez, T., and Joly, J. (1985). Seasonal variations of androgens, estrogens, and progesterone in the different lobules of the testis and in the plasma of Salamandra salamandra. Gen. Comp. Endocrinol. 58, 211-221.

Le Gac, F., and Loir, M. (1988). Control of testis function in fish: In vitro studies of gonadotropic regulation in the trout (Salmo gairdneri). Reprod. Nutr. Dev. 28, 1031-1046.

Levy, H., Deane, H. W., and Rubin, B. L. (1959). Visualisation of steroid-3 $\beta$-ol deshydrogenase activity in tissues of intact and hypophysectomised rats. Endocrinology 65, 933-943.

Loir, M. (1988). Trout Sertoli and Leydig cells: Isolation, separation, and culture. Gamete Res. 20, $437-458$.
Loir, M. (1989). Trout Sertoli cells and germ cells in primary culture. I. Morphological and ultrastructural study. Gamete Res. 24, 1-19.

Loir, M. (1990). Trout steroidogenic testicular cells in primary culture. I. Changes in free and conjugated androgen and progestagen secretions: Effects of gonadotropin, serum, and lipoproteins. Gen. Comp. Endocrinol. 78, 374-387.

Loir, M., Margeridon, A., and Cauty, C. (1988). Leydig cells in Myleus ternetzi testes. Aquat. Living Resour. 2, 57-61.

Nagahama, Y. (1986). Testis. In "Vertebrate Endocrinology: Fundamentals and Biomedical Implications" (P. K. T. Pang and M. P. Schreibman, Eds.), pp. 399-437. Academic Press, New York.

Nagahama, Y. (1987). Gonadotropin action on gametogenesis and steroidogenesis in teleost testis. Zool. Sci. 4, 209-222.

Nicholls, T. J., and Graham, G. P. (1972). The ultrastructure of lobule boundary cells and Leydig cell homologs in the testis of a Cichlid fish, Cichlasoma nigrofasciatum. Gen. Comp. Endocrinol. 19, 133-146.

Philips, H. J. (1973). Dye exclusion tests for cell viability. In "Tissue Culture" (R. F. Kruse and M. K. Patterson, Eds.), pp. 406-408. Academic Press, New York.

Saad, A., and Depéche, J. (1987). In vitro effect of salmon gonadotropin on the testicular synthesis of androgens and of a progestin, 17 $\alpha$-hydroxy$20 \beta$-dihydroprogesterone, in the rainbow trout (Salmo gairdneri). Reprod. Nutr. Dev. 27, 423439.

Terqui, M., Dray, F., and Cotta, J. (1973). Variations de la concentration de l'estradiol-17 $\beta$ dans le sang peripherique de la brebis au cours du cycle oestral. C.R. Acad. Sci. Paris. Ser. D 277, 17951798.

Ueda, H., Kambagewa, A., and Nagahama, Y. (1984). In vitro 11 -ketotestosterone and $17 \alpha, 20 \beta$ dihydroxy-4-pregnen-3-one production by testicular fragments and isolated sperm of rainbow trout, Salmo gairdneri. J. Exp. Zool. 231, 435-439.

Upadhyay, S. N. (1977). "Morphologie des gonades immatures et etude experimentale de l'induction de la gametogenese chez la truite arc-enciel juvenile (Salmo gairdneri)," pp. 1-111. Thesis doct. ès sciences, Paris.

Van den Hurk, R., Peute, J., and Vermeij, J. A. J. (1978). Morphological and enzyme cytochemical aspects of the testis and vas deferens of the rainbow trout, Salmo gairdneri. Cell Tissue Res. 186, 309-325.

Verhoeven, G., Cailleau, J., Van der Schueren, B., and Cassiman, J. J. (1986). The dynamics of steroid and adenosine $3^{\prime}, 5^{\prime}$-cyclic monophosphate 
output in perifused interstitial cell aggregates derived from prepubertal rat testes. Endocrinology 119, 1476-1488.

Verhoeven, G., Cailleau, J., Van Damme, J., and Billiau, A. (1988). Interleukin-1 stimulates steroidogenesis in cultured rat Leydig cells. Mol. Cell. Endocrinol. 57, 51-60.

Wiebe, J. P., Buckingham, K. D., Wood, P. H., and
Campbell, S. M. C. (1987). Relative steroidogenic activity of Sertoli and Leydig cells and role of the Sertoli cell steroid, $3 \alpha-$ hydroxy-4-pregnen-20one, in spermatogenesis and FSH secretion. In "Development and Function of the Reproductive Organs"' (M. Parvinen, I. Huhtaniemi, and L. J. Pelliniemi, Eds.), Vol. 14, pp. 39-53. Raven Press, New York. 